Egypt. Acad. J. Biolog. Sci., 5(1): 37 - 42 (2013)

Email: egyptianacademic@yahoo.com

Received: 12 / 6 / 2013
C. Physiology \& Molecular Biology

ISSN: 2090-0767

www.eajbs.eg.net

\title{
Evaluation of Hematological Parameters of Sudanese Pregnant Women attending at Omdurman Al Saudi Maternity Hospital
}

\author{
Mahmoud Mohamed Elgari \\ Taibah University - college of applied medical sciences - laboratory department - \\ KSA- Almadinah \\ E-mail: elgari999@yahoo.com
}

\begin{abstract}
Background: There are subtle and substantial changes in hematological parameters during pregnancy and the puerperium total blood volume increases by about 1.5 liter mainly to supply the needs of the new vascular bed(Taylor, 1979). Pregnant places extreme stresses on the hematological system and understanding of the physiological changes that result as obligatory in order to interpret any need for therapeutic intervention. (William and Cindy 2005). Iron deficiency is the most common cause of anemia in pregnancy (Odekule 2010). As consequences various quantitative and qualitative hematological changes occur during pregnancy including cell counts, hemoglobin levels, hematocit, leucocytes, thrombocytes, red blood cells indices, morphological changes and reticulocyte production index. (Lewis et al. 2001).

Methods: This a case control study in which 100 pregnant women were enrolled as study group and 50 non pregnant healthy women as control subjects. The study was conducted at Omdurman Al Saudi Maternity Hospital in period from 5/3/ 2011 to 6/6/2011 to evaluate hematological parameters of Sudanese pregnant and to establish classification of anemia's on bases of complete blood count (CBC), reticulocyte production index (RPI) and peripheral blood picture.
\end{abstract}

Results: The study revealed that there were significant decreased in RBCs count, hemoglobin $(\mathrm{Hb})$ and packed cell volume $(\mathrm{PCV})$ of pregnant women compared to non pregnant women $(\mathrm{P}$ value $<0.05)$ and significant decreased in mean corpuscular volume $(\mathrm{MCV})$, mean corpuscular hemoglobin $(\mathrm{MCH})$ and mean corpuscular hemoglobin concentration (MCHC) of pregnant women ( $\mathrm{P}$ value $<0.05$ ). TWBCs count was increased significantly $(\mathrm{P}$. value $<0.050)$ in contrast platelets count significantly lower than the normal control (P. value $<0.05)$. On bases of blood picture we classified anemia's of pregnancy as normocytic normochromic 37 (37\%) with RPI mean value of $0.49 \pm 0.2$, microcytic hypochromic $52(52 \%)$ with RPI mean value of $0.76 \pm 0.6$, and dimorphic picture11 (11\%) with RPI of mean value $2.1 \pm 0.8$.

Conclusion: We observed significant decreased in RBC count, hemoglobin, PCV, red cell indices and platelet count during pregnancy and significant increased in leukocyte count of pregnant women when compared to non pregnant women. We found the most common type of anemia among Sudanese pregnant women is microcytic hypochromic type and likely to be of iron deficiency second class is normocytic normochromic type, and less of occurrence type is dimorphic picture types with increased reticulocyte production index results from prophylaxes iron response.

Keywords: Complete blood count (CBC), Packed cell volume (PCV), Mean Corpuscular volume (MCV), Mean corpuscular hemoglobin $(\mathrm{MCH})$, Mean Corpuscular hemoglobin concentration (MCHC), Reticulocyte production index (RPI)

INTRODUCTION

The majority of pregnant women with hemoglobin values of less than 10 $\mathrm{gm} / \mathrm{dl}$ are suffering from iron deficiency anemia the demands of previous pregnancies render women especially 
prone to iron deficiency, particularly when the interval between pregnancies is shorts (Firki et al. 2002). Physiological anemia is the term often used to describe the fall in hemoglobin concentration that occurs during normal pregnancy results from plasma volume increases above normal by the end of gestation although the red cell masses it self increases by some and still leads to a fall in hemoglobin concentration with a feature of normocytic and normochromic type of anemia (Hoffbrond et al. 2003) Iron deficiency and megaloblastic anemia's during pregnancy result from inadequate intake of folate and iron to meet the increase requirements of pregnancy. The prevalence of megaloblastic anemia among pregnant is varies in different populations, apparently depending on the nutritional status of the population in well nourished communities, (Firki et al., 2002). It is hard to define a normal reference range for $\mathrm{Hb}$ during pregnancy and the limit for diagnosing anemia. The World Health Organization has suggested that anemia is present in pregnancies when $\mathrm{Hb}$ concentration is less than 11 $\mathrm{g} / \mathrm{dL}$. However, Red cell count and PCV values are likewise lower in pregnancy, but the other red cell indices changes little, although red cells show more variation in size and shape than in the non-pregnant state. (Milman et al.., 2007). White cell count increased during pregnancy with a typical reference range of $6 \times 10^{9}-16 \times 10^{9} / \mathrm{L}$, only WBC more than $16 \times 10^{9} / \mathrm{L}$ is considered abnormal (Edlestam et al., 2001). By 4 weeks post-delivery, typical WBC ranges are similar to those in healthy non-pregnant women $\left(4 \times 10^{9}-10 \times 10^{9} / \mathrm{L}\right)$. There has been much discussion about the normal ranges for the different types of white cells (Valdimarsson et al. 1983). Neutrophils contribute most to the overall higher WBC (Edlestam et al., 2001. Leuocytosis relatively constant throughout gestation, markedly elevated in the hours after delivery (up to $23 \times$
$10^{9} / \mathrm{L}$ ) and back to non-pregnant values by 4 weeks post-partum. Typical pregnancy range for lymphocyte count is $1.1 \times 10^{9}-2.8 \times 10^{9} / \mathrm{L}$, compared with the non-pregnant reference range $0.8 \times 10^{9}-$ $4.0 \times 10^{9} / \mathrm{L}$. Lymphocyte count is restored to normal range by 4 weeks after delivery (Firki et al. 2002). Myelocytes and metamyelocytes may be found in the peripheral blood film of healthy women during pregnancy and do not have any pathological significance. platelet count decreases during pregnancy, particularly in the third trimester reported by Boehlen et al. 2000 termed "gestational thrombocytopenia." found to have a platelet count of less than $150 \times 10^{9} / \mathrm{L}$ late in pregnancy (Anne Stiene et al., 1998). None pregnant woman had complications related to thrombocytopenia and none of their babies had been affected (Levy and Murphy., 2002) (Beilin et al., 2006). Thus, it has been recommended that the lower limit of platelet count in late pregnancy considered to be up to $115 \times$ $10^{9} / \mathrm{L}$ reported by Vincelot et al. 2001.

\section{MATERIALS AND METHODS}

This a case control study was conducted at Omdurman Al Saudi Maternity Hospital during the period $5 / 3 / 2011$ to $6 / 6 / 2011$ to evaluate hematological parameters and to establish classification of anemia's of Sudanese heath pregnant women. 2.5 $\mathrm{ml}$ of venous blood was collected from each pregnant and non pregnant woman under sterile condition and drained into $E^{2}$ DTA container with (Lewis et al., 2006) complete blood count was estimated using automated hematological analyzer Sysmex 21.

Peripheral thin blood films were prepared and stained by Leishman stain for red cells morphological study. Some portion of red cells stained supravitally in $1 \%$ cresyl blue stain and reticulocyt production indices were calculated. All obtained Data analyzed using statistical 
package for social science (SPSS) version 11.5 using independent $t$ test significant level set at ( $\mathrm{P}$ value $\leq 0.05)$.

Ethical Considerations: enrolled pregnant women were informed about the study objectives; informed consent was obtained from each. personal information will be kept and not published or permute.

\section{RESULTS}

The study included 100 health pregnant women as study subjects with age mean $37 \pm 3.0$ years and 50 health non pregnant women as control subjects with age mean of $36 \pm 4.3$ years. There is no significant difference in age between study group and control group ( $\mathrm{P}$. value 0.372 ) - (Table 1).

Table1: Characteristics of the study population

\begin{tabular}{lcc}
\hline Pregnant women & non pregnant & P value \\
\hline Number & 50 & \\
100 & & \\
$\begin{array}{l}\text { Age group year (mean } \pm \text { SD) } \\
37 \pm 3.0\end{array}$ & $36 \pm 3.4$ & 0.372 \\
\hline
\end{tabular}

Table shows the data of the age group mean \pm SD for pregnant and non pregnant women

The mean of RBCs count, $\mathrm{Hb}$ and PCV were $3.7 \pm 0.6,9 \pm 1.6$ and $27.7 \pm 5$ significantly lower than control group (P respectively for the study group, were

value $<0.05)$ (Table 2$)$.

Table 2: Hematological parameters of pregnant and nonpregnant women

\begin{tabular}{l|l|l|l}
\hline \multicolumn{1}{c|}{ Parameter } & Pregnant women & None pregnant women & P value \\
\hline $\mathrm{HB} \mathrm{gm} / \mathrm{dl}$ & $9 \pm 1.6$ & $12.0 \pm 0.7$ & 0.001 \\
\hline $\mathrm{PCV} \%$ & $27.7 \pm 5$ & $35.0 \pm 2.3$ & 0.002 \\
\hline $\mathrm{RBC} \times 10^{12} / 1$ & $3.7 \pm 0.6$ & $4.2 \pm 0.3$ & 0.002 \\
\hline $\mathrm{MCV} / \mathrm{fl}$ & $73.8 \pm 9.2$ & $83.5 \pm 3.1$ & 0.001 \\
\hline $\mathrm{MCH} / \mathrm{pg}$ & $24.4 \pm 3.4$ & $28.6 \pm 1.6$ & 0.001 \\
\hline $\mathrm{MCHC} / \mathrm{gm} / \mathrm{dl}$ & $33 \pm 2.8$ & $34.1 \pm 1.2$ & 0.002 \\
\hline $\mathrm{RPI}$ & $0.2 \pm 0.1$ & $0.7 \pm 0.5$ & 0.001 \\
\hline WBC $\times 10^{9} / 1$ & $8.3 \pm 2.3$ & $7.5 \pm 2.4$ & 0.050 \\
\hline Platelet $\times 10^{9} / 1$ & $212 \pm 65$ & $260 \pm 66$ & 0.001 \\
\hline \multicolumn{2}{l}{ The table shows the data as mean values \pm standard deviation } \\
Significant $(\leq 0.05)$ compared to control group (None pregnant women)
\end{tabular}

The mean of MCV was $73.8 \pm 9.2$, $\mathrm{MCH}$ was $24.4 \pm 3.4$ and $\mathrm{MCHC}$ was $33 \pm 2.8$ were significantly lower than normal control $(P$. value $<0.05$ ) (Table 2 ). The mean of RPI of study group was $0.7 \pm 0.5$ significantly higher than the mean of normal control was $0.2 \pm 0.1$
(P. value 0.05 ) (Table 3). The mean of TWBCs count was $8.3 \pm 2.3$ was significantly higher than control group $(\mathrm{P}$. value $<0.050)$ the mean of platelets was $212 \pm 65$ significantly lower than the normal control $(\mathrm{P}$. value $<0.05)$ (Table 3).

Table3: Hematological parameters characterized pattern of anemia among pregnant women

\begin{tabular}{l|l|l|l|l}
\hline \multicolumn{1}{c|}{ Parameter } & Normochromic normocytic & Microcytic hypochromic & Dimorphic picture & Control \\
\hline HB gm/dl & $9.6 \pm 1.1^{*}$ & $8 \pm 1.8^{*}$ & $9.1 \pm 1.2^{*}$ & $12 \pm 0.7$ \\
\hline PCV \% & $29 \pm 3.6^{*}$ & $26.2 \pm 0.7^{*}$ & $26.6 \pm 3.3^{*}$ & $35 \pm 2.3$ \\
\hline RBC $x 10^{12} / 1$ & $3.5 \pm 0.05^{*}$ & $3.8 \pm 0.7^{*}$ & $3.9 \pm 0.5^{*}$ & $4.2 \pm 0.3$ \\
\hline RPI & $0.49 \pm 0.2$ & $0.76 \pm 0.6$ & $2.1 \pm 0.8^{*}$ & $0.7 \pm 0.5$ \\
\hline
\end{tabular}

The table shows the data as mean values \pm standard deviation. 
* Significant $(\leq 0.05)$ compared to control group (None pregnant women)

According to peripheral blood were microcytic hypochromic and picture $37(37 \%)$ of study group were 11(11\%) were dimorphic (Fig. 1).

normocytic normochromic, 52(52\%)

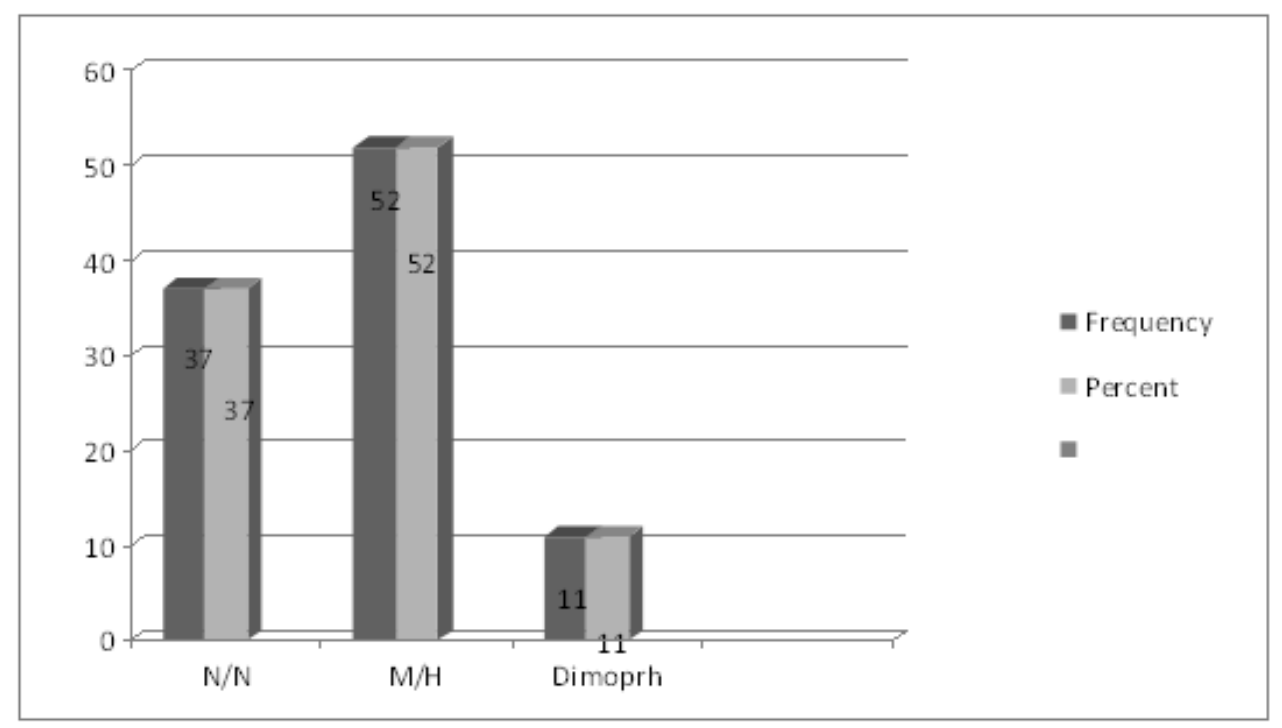

Fig. 1: Pattern of peripheral blood picture among study group- $\mathrm{N} / \mathrm{N}=$ Normoctic and normochromic $\mathrm{M} / \mathrm{H}=$ Microctic and hypochromic.

The results related to normocytic normochromic showed showed the mean of $\mathrm{Hb}, \mathrm{RBCs}, \mathrm{PCV}$ and RPI were $9.6 \pm 1.1,3.5 \pm 05,29 \pm 3.6$ and $0.49 \pm 0.2$. Mictocytic hypochromic showed the mean of $\mathrm{Hb}, \mathrm{RBCs}, \mathrm{PCV}$ and RPI were $8.5 \pm 1.8,3.8 \pm 0.7,26.2 \pm 5.7$ and $0.76 \pm 0.6$ respectively. Dimorphic blood picture showed $\mathrm{Hb}, \mathrm{RBCs}, \mathrm{PCV}$ and RPI were $9.1 \pm 1.2, \quad 3.9 \pm 0.5, \quad 27.6 \pm 3.3$ a $2.1 \pm 0.8$ respectively.

\section{DISCUSSION}

Pregnancy causes significant changes in metabolism, fluid balance, organ function and blood circulation which are driven by estrogen and the presence of the feto - placental unit. These dramatic changes influence a wide variety of hematological parameters. Acknowledge of these changes is essential when interpreting the result of hematological investigation to diagnose or monitor illness pregnant woman. The study revealed significant decreases in RBCs count, HB and PCV respectively of pregnant women compared to non pregnant women $(\mathrm{P}$. value $<0.05)$. Also $\mathrm{MCV}, \mathrm{MCH}$ and $\mathrm{MCHC}$ were significantly lower in pregnant women compared to non pregnant women ( $\mathrm{P}$ .value $<0.05)$. The findings are consistent with previous study which reported that the decreases in hemoglobin and red cell indices concentration are common findings during pregnancy and results from increased plasma volume combined poor iron intake (Bashiri, et al. 2003), (Ruchi et al. 2013). We found significant increased WBC count significant higher compared to that of the controls. The finding in agreement with previous study reported that total leukocyte count rising in early pregnancy and remained elevated through pregnancy. This may be as a result of the body building the immunity of the fetus and it is achieved by a state of selective immune tolerance, in the presence of a strong antimicrobial immunity. Similarly to the previous study reported that pregnancy leucocytosis, primarily 
related to increased circulation of neutrophils in the second month of pregnancy (Rouse et al., 1998).

Significant decreases in platelet count of pregnant women compared to non pregnant women $(P . v a l u e<0.05)$ in agreement with study reported that: although platelet counts remain in the normal pregnant range in most women during uncomplicated pregnancies (Matthews et al., 1990). mean platelet counts of pregnant women may be slightly lower than in healthy non pregnant women (Verdy et al., 1997).

Peripheral blood picture of the study group revealed existence of three patterns of anemia's among pregnant women the majority was microcytic and hypochromic type of anemia 52(52\%) with significant decreases in $\mathrm{Hb}$, red cell count and PCV considered to be the highest type of anemia among pregnant women, second pattern is normocytic and normochromic type anemia was 37(37\%) with significant decreases in $\mathrm{Hb}$, red cell count and PCV is coming as second class, and third pattern is dimorphic picture type was $11(7.3 \%)$ with significant decreases in $\mathrm{Hb}$, red cell count and PCV and significant increased RPI indicated effective of erythropoisis which related to iron responses. Similar result reported in Pakistan by Khalil, et al., 2007.

\section{REFERENCES}

Anne Stiene-Martin E. Cheryl, A. Lotspeich-Steininger. John, A. K. (1998). Clinical Haematology, principle, procedure and correlation. $2^{\text {nd }}$ ed. Philadilphia: Lippincott- Raven.

Bashiri, A. Burstein, E. Sheiner, E. and Mazor, M. (2003). Anemia during pregnancy and treatment with intravenous iron: review of litreture, Eur J Obstet Gynecol Repord Biol, 110(1): 2-7.

Beilin Y, Arnold I, Hossain S. (2006). Evaluation of the platelet function analyzer (PFA-100 R_) vs. the thromboelastogram (TEG) in the parturient. International Journal of Obstetric Anesthesia; 15: 7-12.

Boehlen F., Hohfeld P., Extermann P. (2000). Platelet count at term pregnancy: a reappraisal of the threshold. Obstetrics and Gynecology, 95: 29-33.

Edlestam G, Lowbeer C, Kral G. (2001). New reference values for routine blood samples and human neutrophilic lipocalin during third trimester pregnancy. Scandinavian Journal of Clinical Laboratory Investigation, 61: 583-592.

Firki, F. C. Chesterma, C. N. Peningto, D. G and Rus, B. M., (2002). de Gruchy's Clinical Haematology in Medical Practice. $5^{\text {th }}$ ed. London: Blackwell Publishing Ltd.

Hoffbrand. a. v, pettit., (2003). essential hematology fourth edition page: 319-320

Khalil, A. A. Jabbar, T. Akhtat, S. Mohyaddin, S. (2007). Frequency and types of anemia in an antenatal clinical in the third trimester of pregnancy. Pakistan Armed Forces Medical Journal.

Levy, J. A. and Murphy, L. D., (2002). thrombocytopenia in pregnancy. $\mathrm{J}$ Am Board Fam Pract, 15(4): 290-7.

Lewis, S. M. Bain, B. J. Bates, I. (2001). Dacie and Lewis Practical Hematology. $9^{\text {th }}$ ed. London : Churchill Livingstone.

Matthews JH, Benjamin S, Gill DS, Smith N A. (1990). Pregnancyassociated thrombocytopenia: definition, incidence and natural history. Acta Haematol, 84:24.

Milman N, Bergholt T, Byg K-E. (2007). Reference intervals for hematological variables during normal pregnancy and postpartum in 434 healthy Danish women. European Journal of Hematology; 79: 39-46. 
Odekule, A. (2010). Anemia in pregnancy associated with parity, abortion and child scalping in primary healthcare clinical attended in Trinidad and Tobago. African Health Science, 10(1):66-70.

Rouse DJ, Owen J., Goldenberg RL. (1998). Routine maternal platelet count: an assessment of a technologically driven screening practice. Am J Obstet Gynecol; 179:573.

Ruchi Kothari1, Pradeep Bokariya 2, Varun Kothari Jan.-Feb (2013). A Study of Erythron Status in Pregnant \& Non-Pregnant Age Matched Females of Jodhpur IOSR Journal of Pharmacy Vol. 3,

Taylor DJ, Lind T. (1979). Red cell mass during and after normal pregnancy.
British Journal of Obstetrics and Gynecology; 86: 364-370.

Valdimarsson $\mathrm{H}$, Mulholland C, Fridriksdottir $\mathrm{V}$ et al. 1983 A longitudinal study of leucocyte blood counts and lymphocyte responses in pregnancy

Verdy E, Bessous V, and Dreyfus M. (1997). Longitudinal analysis of platelet count and volume in normal pregnancy. Thromb Haemost; 77:806.

Vincelot A, Nathan N, Collert D. (2001). Platelet function during pregnancy: an evaluation using the PFA-100 analyser. British Journal of Anaesthesia; 87:

William, J.G and Cindy, L.S. (2005). Principles of human physiology. $2^{\text {nd }}$ ed. United State: Dary Fox.

\section{ARABIC SUMMARY}

تقييم دلالات مكونات الام الكلية في النساء الحوامل السودانيات في مستثفي امدرمان السعودي للولادة

$$
\text { جامعة طيبة ـ كلية العلوم الطبية التطبيقية ـ قحمد المختبر ات ـ المدينة المنورة ـ السعودية }
$$

هذه در اسة وصفيه تحليليه (حالة وحالة ضابطة) أجريت بمستشفي امدرمان السعودي للو لادة في الفترة

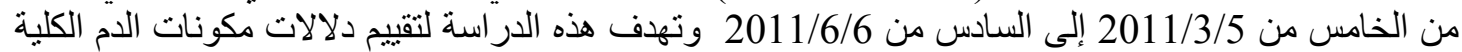

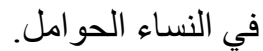

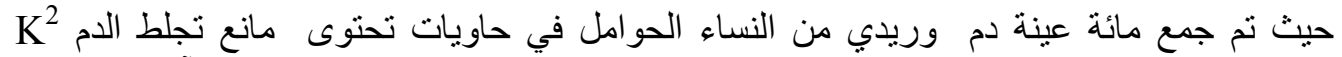
طرّق القياس:

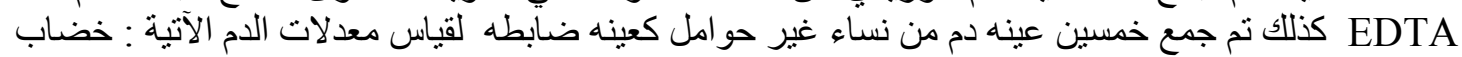

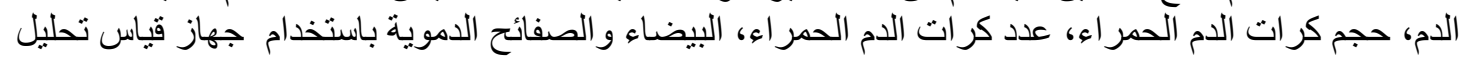

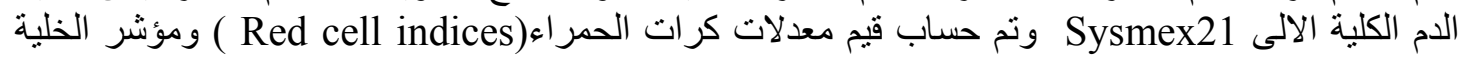

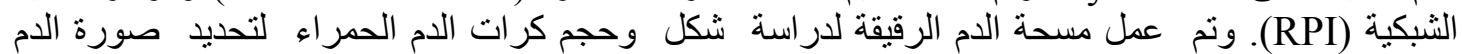

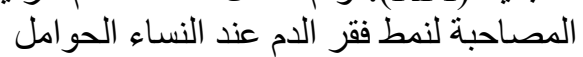
النتائج:

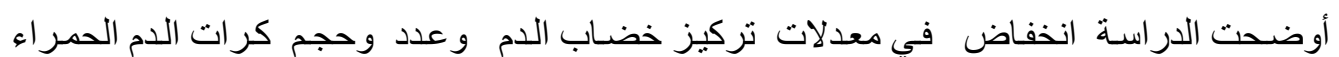

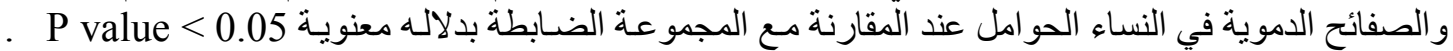
بينما هنالك زيادة بدلالة معنو ية في عدد كرات الدم البيضاء

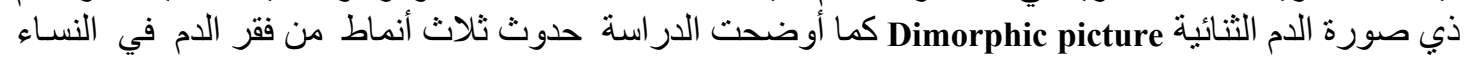

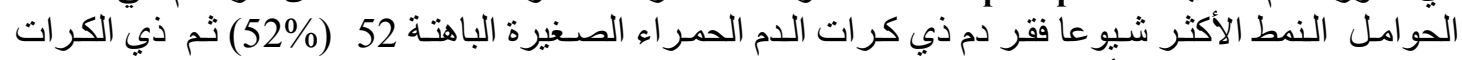

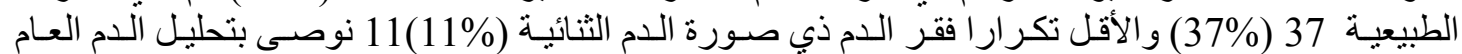

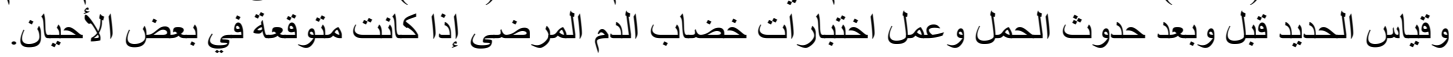

